\title{
OPERATIONAL AND EMPLOYEES PERFORMANCE OF SERBIAN INDUSTRIAL COMPANIES WITH ISO 9001 CERTIFICATE
}

\author{
UDC: 005.96:334.716(497.11) \\ Vesna SPASOJEVIĆ BRKIĆ ${ }^{1}$, Zorica VELJKOVIĆ ${ }^{2}$, Nada STANOJEVIĆ ${ }^{2}$, \\ Snezana PAVICEVIĆ ${ }^{3}$ \\ ${ }^{1}$ University of Belgrade, Faculty of Mechanical Engineering, 11000 Belgrade, Kraljice Marije 16, \\ Republic of Serbia, E-mail: vspasojevic @ mas.bg.ac.rs \\ ${ }^{2}$ University of Belgrade, Faculty of Mechanical Engineering, 11000 Belgrade, Kraljice Marije 16, \\ Republic of Serbia \\ ${ }^{3}$ Institute for business improvement Ltd., 11000 Belgrade, Save Maskovica 3///13, Republic of Serbia
}

Original Scientific Paper

Paper received: 11.05.2017.; Paper accepted: 22.05.2017.

\begin{abstract}
Business performance is manifested through key performance indicators, which show the actual state in business enterprises and possible deviations from the business objectives that have been set. Due to new practices in transitional economies it is necessary to track business performance measures on company level. The most frequently studied types of performance in the available literature are quality, operational, market and financial, employee performance, innovation, project, aggregate firm performances, and customer satisfaction. This study empirically examines operational and employees performance on a sample of 113 Serbian industrial companies. After data collection through questionnaire usage, descriptive statistics, factor and reliability analysis were used to check if description of examined performances could be done using dimensions proposed according to results of the previous research in a statistically significant way. Examined operational and employees performances provided, have proved valid and reliable dimensions of Serbian industrial companies as a construct. The obtained results comply with previous research done in other countries and contexts. Future research could consist of a longitudinal study but as an examination of operational and employees` performance measures in other Serbian industrial sectors, too. Also, the relationship between operational and employees performance measures could be explored.
\end{abstract}

Keywords: Operational performance, Employee performance, Companies, Serbia.

\section{INTRODUCTION}

The transition processes are characteristic for a large part of the world economy, including the countries of the former USSR, Bulgaria, Romania, Hungary, and also the countries of former Yugoslavia. Serbia's transition process has taken place about a quarter of a century. The liberalization of trade relations and capital balance has enabled the integration of the economic system of Serbia in international financial and commodity flows. As a consequence of those integrations, companies in Serbia are in the phase of introducing new trade procedures and new legislatives, with wide foreign investments in domestic companies. It results in high demand for radical organizational changes due to new business ambience (Dondur, Pokrajac, Spasojević-Brkić, \& Grbić, 2011; Živković, Mihajlović, \& Prvulović, 2009). Survival on the market and a good business performance are the main aims of contemporary companies that are not easily reached together with necessary organizational and structural changes.

Due to implementation of new practices it is necessary to track performance measures at company level. The most frequently studied types of performance in available scientific references are: quality performance, operational performance, market and financial performance, employee performance, customer satisfaction, innovation performance, project performance and aggregate firm performance, (Sadikoglu \& Zehir 2010). 
Operational performance of the company is one of very important types of firm's performance that measures results of the company according to standard or prescribed indicators of effectiveness, and efficiency such as cycle time, productivity, quality, waste reduction and regulatory compliance.

Employees performance is also a very important measure since it was noticed a long time ago that motivation, attitude and perception of employees influenced organizations' functioning (Khandwalla, 1977). It is also known that structural changes significantlly influence employees performance results (Argyris, 1993).

Since Serbian industrial context emphasizes structural changes, it is very important to analyze companies' operational performance. Empirical study on the sample of 113 Serbian industrial companies is the main aim of this survey in order to determine evidences that come about companies operational and employees` performance.
This survey consists of the following parts. After literature review, operational and employees performance constructs are described with certain dimensions. After data collection on the sample of Serbian industrial companies, the data are undergone to multivariate statistics, factor and reliability analysis. Finally, the results will show if the proposed dimensions belong to constructs operational and employees' performance.

\section{PREVIOUS RESEARCH}

Business performance is manifested through key performance indicators, which show the actual state in business enterprises and possible deviations from the business objectives that have been set.

Review of business performance has been tracked from available literature sources in different ways, as can be seen in Table 1. It can be noticed that operational and employees performance is a very important performance measure. There are also other important measures such as financial, market, social and other measures.

Table 1: Business performances in previous researches

\begin{tabular}{|c|c|}
\hline AUTHOR & PERFORMANCE MEASURES \\
\hline $\begin{array}{l}\text { Fuentes-Fuentes, } \\
\text { Albacete-Sáez and } \\
\text { Lloréns-Montes (2004) }\end{array}$ & $\begin{array}{l}\text { - financial (total revenue, profitability) } \\
\text { - operational (defective products, rework, customer satisfaction) } \\
\text { - employee performance (employee satisfaction, absence from work) }\end{array}$ \\
\hline $\begin{array}{l}\text { Demirbag, Lenny Koh, } \\
\text { Tatoglu and Zaim } \\
(2006)\end{array}$ & $\begin{array}{l}\text { - financial (total revenue, net profit, profit/expense ratio) } \\
\text { - non-financial (investment in research and development, extension in } \\
\text { capacities, new product development, larger market share, expansion on new } \\
\text { markets) }\end{array}$ \\
\hline Lai (2003) & $\begin{array}{l}\text { - motivational (employee earnings and benefits, employee trainings, employee } \\
\text { satisfaction, job security, work safety) } \\
\text { - } \text { market (development and innovation of new and existing products, } \\
\text { competitive product price, costumer complains) } \\
\text { - productivity (efficiency in material, work force, capacities usage) } \\
\text { - } \text { societal (benefits for society and community) }\end{array}$ \\
\hline $\begin{array}{l}\text { Samson and Terziovski } \\
\text { (1999) }\end{array}$ & $\begin{array}{l}\text { - market (customer expectations fulfillment) } \\
\text { - employee contentment (employees' moral and satisfaction) } \\
\text { - operational (share of defective products, costs in the warranty period, quality } \\
\text { costs, share of timely deliveries) }\end{array}$ \\
\hline Everett et al. (1997) & $\begin{array}{l}\text { - financial } \\
\text { - operational } \\
\text { - employees performance }\end{array}$ \\
\hline Tari and Sabater (2004) & $\begin{array}{l}\text { - customer satisfaction } \\
\text { - employees satisfaction } \\
\text { - societal benefits } \\
\text { - operational performances }\end{array}$ \\
\hline
\end{tabular}


In the context of operational measures, certain previous works should be mentioned. Hendricks and Singhal (1997) have explored the impact of effective Total Quality Management - TQM implementation on operational performance which resulted in the conclusion that firms winning quality awards outperformed those in a matched control sample without such awards. Sharma (2005), Samson and Terziovski (1999), and Lemak, Reed and Satish (1997) have concluded that quality improvement practices improve business performance, too. They also presented significant proofs for financial and operational performance improvement. Spasojević Brkić, Djurdjević, Dondur, Klarin and Tomić (2013), Spasojević Brkić, Klarin, Brkić, Lučanin and Milanović (2011), Sadikoglu and Zehir (2010) and Samson and Terziovski (1999) for measuring operational performance determined the following five crucial dimensions:

- Customer satisfaction

- The share of defective products in relation to the volume of production

- The cost of the warranty period as compared to total sales

- Quality costs in relation to total revenue and

- Proportion of timely deliveries in total deliveries.

It is very important to design jobs so that employees stress factors can be reduced in aim to enhance their motivation, improve their satisfaction and performance (Garg \& Rastogi, 2006, Tomić, Spasojević-Brkić, \& Klarin, 2012, Terziovski \& Samson, 1999). It further leads to effective competition potential of the company in the global marketplace (Garg \& Rastogi, 2006). According to Bass, Avolio and Atwater (1996), employees perform tasks through identification with a leader or with their organization. It means that they make basic agreement with the norms to which they are required to perform (Bass et al., 1996). Vroom (1964) points out that better performance can be achieved when a reasonable level of expectation-fit exists and when the social exchange between managers and employees is fair and equal. Andrews and Kacmar (2001) highlight that employees tend to achieve self-interests, advantages, and benefits at the expense of others and sometimes contrary to the interests of the entire company. Employees even tend to promote their interests more aggressively in an environment that works with limited resources (Vigoda-Gadot, 2007). Love and Edwards (2005) in their study have proved that perceived work demands, job control and social support through job design leads to higher productivity results.

Literature sources such as Sadikoglu and Zehir (2010), Spasojević Brkić et al. (2013), Skerlavaj, Štemberger and Dimovski (2007) and Spasojević Brkić et al. (2011) propose the following common dimensions for employees' performance description:

- Employees moral

- Employees productivity

- Employees absenteeism rates and

- Wages and other employees` benefits.

\section{METHODOLOGY AND RESULTS ON OPERATIONAL AND EMPLOYEES PERFORMANCE}

Data for study of industrial enterprises in Serbia were collected using a questionnaire formed for this purpose. Respondents were required to mark the value of operational and employees' performance dimensions rating at a Likert scale from 1 to 5. Performance concepts and dimensions are consistent with and discussed in detail in Spasojević Brkić et al. (2011), while the performance measurements are consistent with previous research (Nair, 2006).

The survey population consists of 969 ISO 9001 certified industrial companies. Based on the experience of other researchers, in order to represent population in good manner, 250 industrial companies were chosen for the survey, including 40 large, 80 medium-sized and 130 small companies.

Distribution of the survey was conducted via email. Responses were received from 119 industrial companies certified according to ISO 9001 management standard, which comprise more than $10 \%$ of the Serbian industrial company population with that characteristic. There was a $47.6 \%$ response rate. The response was worst in small enterprises, as shown in Figures 1 and 2. The average number of employees in the sample was 370.91 , with a standard deviation of 267.98. Our sample proves the fact that almost a third of employees work in large enterprises in Serbia. The answers have been obtained from the persons employed in domestic industrial companies with an average of 16.98 years work experience. The $41 \%$ of the employees were quality department 
directors, 32\% were directors of other technical departments, $22 \%$ employees work in quality departments or quality representatives and $5 \%$ in other managerial positions. Since this survey is a part of the larger survey, it is important to note that data about operational and employees performance is obtained from 113 companies (at maximum), due to missing data. Distribution of size of the ISO 9000 certified companies in Serbia is presented in
Figure 1., while the same distribution for the sample is presented in Figure 2.

Table 2 presents the descriptive statistics for operational business performance collected data.

Table 3 presents the descriptive statistics for employees` business performance collected data.

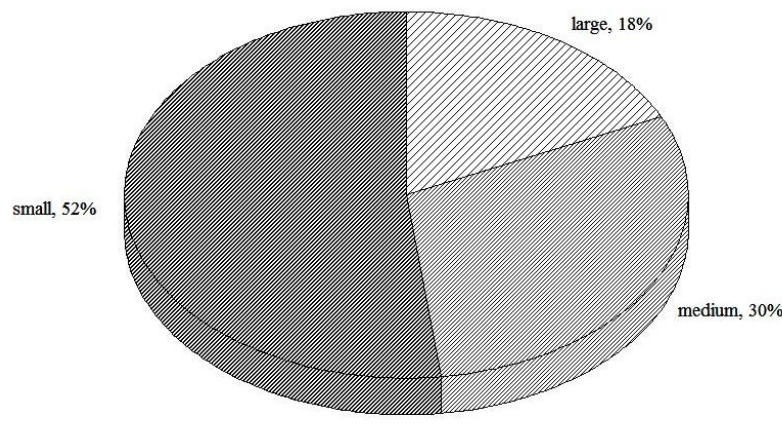

Figure 1: Distribution of certified Serbian industrial companies according to size in population

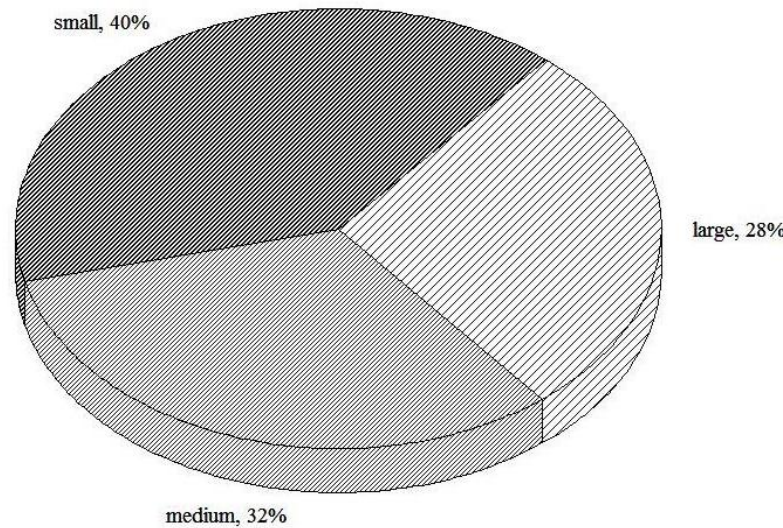

Figure 2: Distribution of certified Serbian companies according to size in the sample

Table 2: Descriptive statistics for operational business performance in Serbian industrial companies

\begin{tabular}{|l|c|c|c|c|c|}
\hline \multicolumn{1}{|c|}{ Operational performance dimensions } & N & Min. & Max. & Mean & Stand. dev. \\
\hline Customer satisfaction & 113 & 1 & 5 & 3.71 & 0.873 \\
\hline $\begin{array}{l}\text { The share of defective products in relation to the volume } \\
\text { of production }\end{array}$ & 104 & 1 & 5 & 3.73 & 1.201 \\
\hline The cost of the warranty period as compared to total sales & 101 & 1 & 5 & 3.64 & 1.339 \\
\hline Quality costs in relation to total revenue & 97 & 1 & 5 & 3.91 & 1.071 \\
\hline Proportion of timely deliveries in total deliveries & 103 & 1 & 5 & 3.77 & 1.156 \\
\hline
\end{tabular}

Table 3: Descriptive statistics for employees` business performance in Serbian industrial companies

\begin{tabular}{|l|c|c|c|c|c|}
\hline Employees performance dimensions & $\mathbf{N}$ & Min. & Max. & Mean & Stand. Dev. \\
\hline Employees moral & 111 & 1 & 5 & 3.50 & 1.026 \\
\hline Employees productivity & 111 & 1 & 5 & 3.35 & 0.891 \\
\hline Employees absenteeism & 109 & 1 & 5 & 3.13 & 0.747 \\
\hline Wages and other employees benefits & 111 & 1 & 5 & 3.72 & 0.974 \\
\hline
\end{tabular}

After descriptive statistics, data are undergone to explorative factor and reliability analysis to check if they are useful in operational performance description in statistically significant way.

Reliability is the degree to which the observed variable measures the "true" value and is "error free" (Hair, Anderson, Tatham, \& Black, 1998). For this study, reliability was estimated through Cronbach $\alpha$ coefficient as an indicator of the amount of present random error in the scale used for measurement (Kaynak \& Hartley, 2006). The value 0.60 has been adopted for the lower level of Cronbach $\alpha$ acceptability. Nunnally (Spasojević Brkić, 2009) suggests the value 0.70 for the lower level, with a large number of researchers adopt this value (Spasojević Brkić, 2009; Handfield, Jayaram, \& Ghosh, 1999). However, values lower than 0.70 can also be seen in numerous studies (Spasojević Brkić V. 2009; Singh, 2008; Conca, Llopis, \& Tarí, 2004; Tari \& Sabater, 2004; Lai, 2003). A coefficient value of 1 means perfect 
reliability (Hair et al., 1998). Cronbach $\alpha$ coefficient is calculated according to the following formula (Cronbach \& Shavelson 2004):

$$
\alpha=\left(\frac{k}{k-1}\right) \cdot\left[1-\sum \frac{S_{i}^{2}}{S_{\text {sum }}^{2}}\right]
$$

where, $k$ - the number of conditions contributing to a total score, $S_{i}^{2}$ - variance for $\mathrm{k}$ individual measurement, and $S_{\text {sum }}^{2}$ - variance for the sum of all measurements.

Explorative factor analysis is a statistical method used to uncover the underlying structure of a certain set of variables. It is used herein with the aim to reduce a larger number of variables to a much smaller set, retaining as much as possible of the variation. Explorative factor analysis is conducted using principal components with Varimax rotation and Kaiser normalization on the obtained data. It means that given factor matrix with arbitrary reference for $\mathrm{n}$ test and $\mathrm{r}$ factors, Varimax criterion requires orthogonal rotations on this matrix in order to obtain a maximum (Kaiser, 1959):

$$
\sum_{s}\left\{n \cdot \sum_{i}\left(\alpha_{i s}^{2} / h_{i}^{2}\right)^{2}-\left[\sum_{i}\left(\alpha_{i s}^{2} / h_{i}^{2}\right)\right]^{2}\right\}
$$

where: $j=1,2, \ldots, s=1,2, \ldots$, while $n$ represents tests, $r$ represents factors, $\alpha_{i s}$ is the loading for $j$-th test on $s$-th factor and $h_{i}^{2}$ is communality of the $j$-th test.

Only those factors that accounted for variances greater than one, i.e. with eigenvalues $>1$, were extracted. Also, for interpreting the factors relating to sample size, only those items which had factor loadings greater than 0.5 were included (Hair et al., 1998). As can be seen in Figure 3 two factors which accounted for $72.08 \%$ of the total variation in the observed variables were extracted.

In this survey all 5 examined operational performance dimensions are above or very close (0.595) to value of 0.6 of Cronbach $\alpha$, according to results given in Table 5. All factors have loading above 0.5 , as can be seen in Table 4 .

Explorative factor analysis and reliability analysis for all operational performance dimensions are presented in Tables 4 and 5, respectively.

For the conducted explorative factor analysis for operational performance dimensions, Eigen values for factors and values of explained variance and their cumulative values are presented are shown at Figure 3.

Table 4: Explorative factor analysis for operational performance dimensions

\begin{tabular}{|l|c|c|}
\hline \multirow{2}{*}{ Operational performance dimensions } & \multicolumn{2}{|c|}{ Factors } \\
\cline { 2 - 3 } & Factor 1 & Factor 2 \\
\hline Customer satisfaction & $\mathbf{0 . 6 4 1}$ & 0.437 \\
\hline The share of defective products in relation to the volume of production & $\mathbf{0 . 8 9 7}$ & 0.012 \\
\hline The cost of the warranty period as compared to total sales & $\mathbf{0 . 7 7 9}$ & -0.337 \\
\hline Quality costs in relation to total revenue & 0.526 & $\mathbf{- 0 . 6 9 2}$ \\
\hline
\end{tabular}
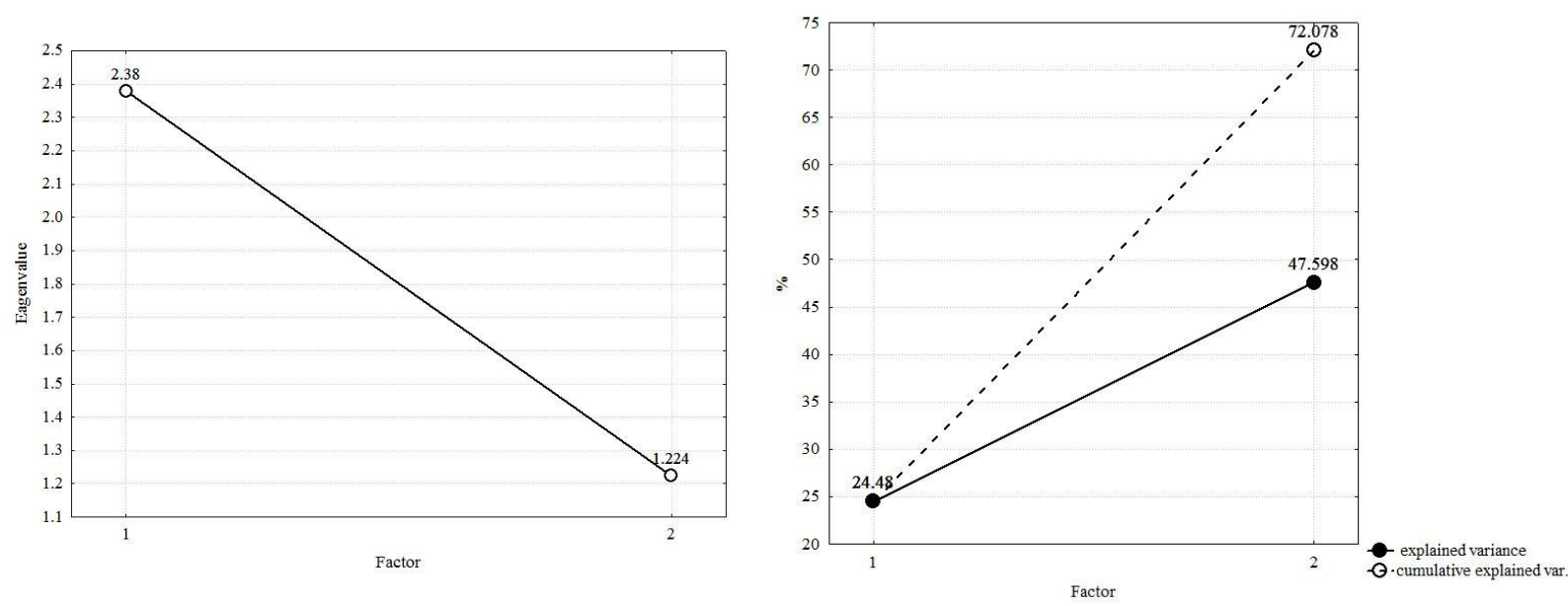

Figure 3: Eigen values, explained and cumulative variance for factors of operational performance 
Table 5: Reliability analysis of operational performance dimensions

\begin{tabular}{|l|c|c|}
\hline \multicolumn{1}{|c|}{ Factor with "items" } & $\begin{array}{c}\text { Corrected item - } \\
\text { total correlation }\end{array}$ & $\begin{array}{c}\text { Cronbach alpha } \\
\text { coefficient } \\
\text { if item is deleted }\end{array}$ \\
\hline Customer satisfaction & 0.421 & 0.796 \\
\hline The share of defective products in relation to the volume of production & 0.733 & 0.421 \\
\hline The cost of the warranty period as compared to total sales & 0.595 & 0.638 \\
\hline Quality costs in relation to total revenue & 0.623 & 0.378 \\
\hline Proportion of timely deliveries in total deliveries & 0.715 & 0.407 \\
\hline
\end{tabular}

Table 6: Explorative factor analysis for employees' performance dimensions

\begin{tabular}{|l|c|c|}
\hline \multirow{2}{*}{ Employees performance dimensions } & \multicolumn{2}{|c|}{ Factors } \\
\cline { 2 - 3 } & Factor 1 & Factor 2 \\
\hline Employees moral & $\mathbf{0 . 8 8 9}$ & -0.196 \\
\hline Employees productivity & $\mathbf{0 . 7 0 1}$ & 0.387 \\
\hline Employees absenteeism & $\mathbf{0 . 6 5 1}$ & $\mathbf{- 0 . 6 7 9}$ \\
\hline Wages and other employees benefits & $\mathbf{0 . 5 7 7}$ & $\mathbf{0 . 6 1 3}$ \\
\hline
\end{tabular}
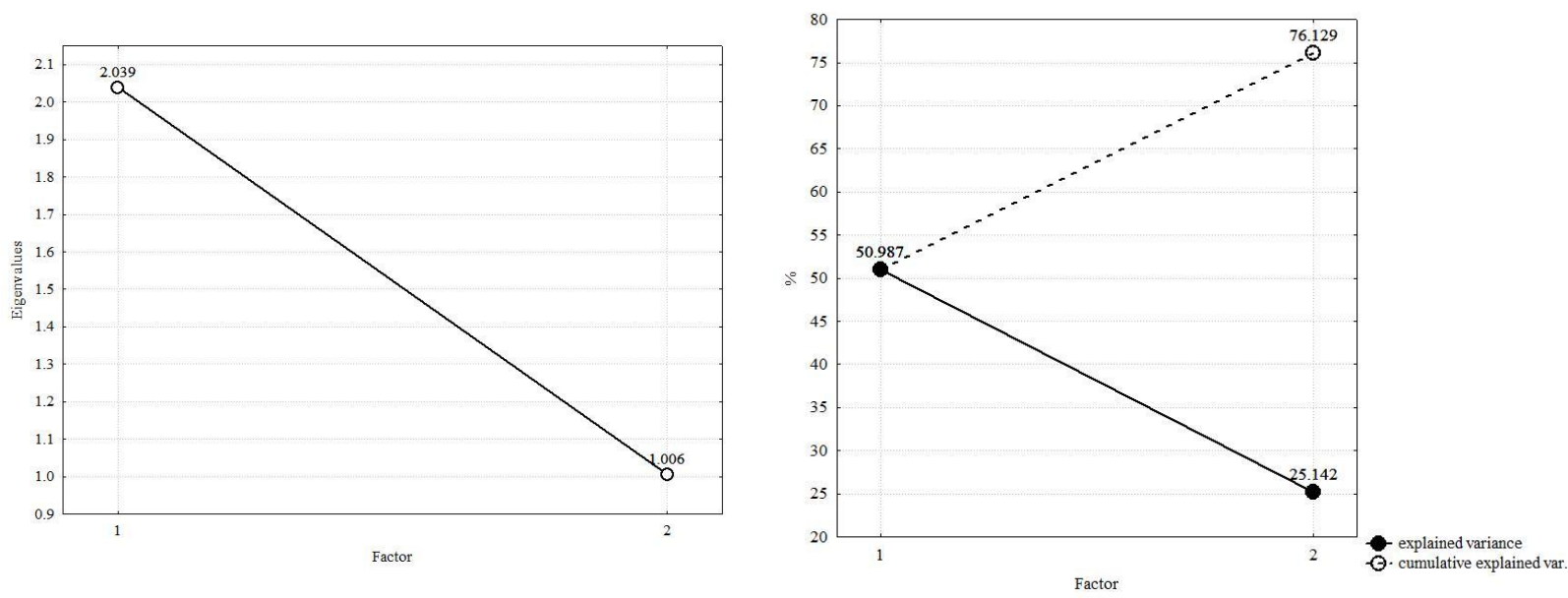

Figure 4: Eigen values, explained and cumulative variance for factors of employees' performance

Table 7: Reliability analysis of employees` performance dimensions

\begin{tabular}{|l|c|c|}
\hline \multicolumn{1}{|c|}{ Factor with "items" } & $\begin{array}{c}\text { Corrected item - } \\
\text { total correlation }\end{array}$ & $\begin{array}{c}\text { Cronbach alpha } \\
\text { coefficient if item is deleted }\end{array}$ \\
\hline Employees moral & 0.613 & 0.416 \\
\hline Employees productivity & 0.611 & 0.418 \\
\hline Employees absenteeism & 0.690 & 0.638 \\
\hline Wages and other employees benefits & 0.733 & 0.421 \\
\hline
\end{tabular}

Explorative factor analysis and reliability analysis for all employees' performance dimensions are presented in Tables 6 and 7, respectively.

Figure 4 represents Eigen values and percentage of explained variances for explorative factor analysis of employees` performance dimensions.

Regarding employees performance, from Tables 6 and 7, can be noticed that all employees' performance dimensions have adequate values both in reliability and factor analysis.

\section{CONCLUSIONS}

This survey comes to the conclusion that it is possible to classify and track operational and employees performance of Serbian companies into pattern as described in this paper using multivariate statistics - factor and reliability analysis. Tracking the operational and employees performance of Serbian companies in the proposed simple manner enables the improving rates of survival on the market and good business performance of domestic companies. 
Accordingly, customer satisfaction, the share of defective products in relation to the volume of production, the cost of the warranty period as compared to total sales, quality costs in relation to total revenue and proportion of timely deliveries in total deliveries have been proved as well as valid and reliable dimensions of operational performance of Serbian industrial companies as a construct.

Also, employees' moral, productivity and absenteeism rates and their wages and other benefits have been proved and as well as valid and reliable dimensions of employees ' performance of Serbian industrial companies as a construct.

Our results comply with those within the framework proposed in previous research done in other countries and contexts. In some further studies, dimension cost reliability of the warranty period as compared to total sales as a part of construct operational performance should be checked.

The limitation of this study lies in the fact that this research is a cross sectional study.

Future research could consist of a longitudinal study. A suggestion for future studies would be an examination of operational and employees performance measures in other Serbian industrial sectors, too. Also, the relationship between operational and employees performance measures could be explored.

\section{ACKNOWLEDGEMENT}

The paper is supported by a grant from the Serbian Ministry of Science under contract TR 35017. The authors also thank the respondents who filled out the questionnaires for their kind cooperation.

\section{REFERENCES}

Andrews, M. C., \& Kacmar, K. M. (2001). Discriminating among organizational politics, justice, and support. Journal of organizational behavior, 22(4), 347-366. doi: 10.1002/job.92

Argyris, C. (1993). Knowledge for action: A guide to overcoming barriers to organizational change. San Francisco, CA: Jossey-Bass Inc., Publishers.

Bass, B. M., Avolio, B. J., \& Atwater, L. (1996). The transformational and transactional leadership of men and women. Applied Psychology, 45(1), 5-34. doi: 10.1111/j.1464-0597.1996.tb00847.x

Conca, F. J., Llopis, J., \& Tarí, J. J. (2004). Development of a measure to assess quality management in certified firms. European journal of operational research, 156(3), 683-697. doi: 10.1016/S0377-2217(03)00145-0

Cronbach, L. J., \& Shavelson, R. J. (2004). My current thoughts on coefficient alpha and successor procedures. Educational and psychological measurement, 64(3), 391-418. doi:

$10.1177 / 0013164404266386$

Demirbag, M., Lenny Koh, S. C., Tatoglu, E., \& Zaim, S. (2006). TQM and market orientation's impact on SMEs' performance. Industrial Management \& Data Systems, 106(8), 1206-1228.doi: 10.1108/02635570610710836

Dondur, N., Pokrajac, S., Spasojević-Brkić, V., \& Grbić, S. (2011). Decomposition of productivity and allocative efficiency in Serbian industry. FME Transactions, 39(2), 73-78.

Everett, A. E. Jr, Corbett, L. M., Flores, B. E., Harrison, N. J., Lee, T. S., Rho, B.-H., ... Westbrook, R. (1997). An international study of quality improvement approach and firm performance. International Journal of Operations \& Production Management, 17(9), 842-873. doi: $10.1108 / 01443579710171190$

Fuentes-Fuentes, M. M., Albacete-Sáez, C. A., \& Lloréns-Montes, J. F. (2004). The impact of environmental characteristics on TQM principles and organizational performance. Omega, 32(6), 425-442. doi: 10.1016/j.omega.2004.02.005

Garg, P., \& Rastogi, R. (2006). New model of job design: motivating employees' performance. Journal of management Development, 25(6), 572-587. doi: 10.1108/02621710610670137

Hair, J. F., Anderson, R. E., Tatham, R. L., \& Black, W. C. (1998). Multivariate data analysis (5th ed.): Upper Saddle River.

Handfield, R., Jayaram, J., \& Ghosh, S. (1999). An empirical examination of quality tool deployment patterns and their impact on performance. International Journal of Production Research, 37(6), 1403-1426. doi: 10.1080/002075499191328

Hendricks, K. B., \& Singhal, V. R. (1997). Does implementing an effective TQM program actually improve operating performance? Empirical evidence from firms that have won quality awards. Management science, 43(9), 1258-1274. doi: 10.1287/mnsc.43.9.1258

Kaiser, H. F. (1959). Computer program for varimax rotation in factor analysis. Educational and psychological measurement, 19(3), 413-420.

Kaynak, H., \& Hartley, J. L. (2006). Using replication research for just-in-time purchasing construct development. Journal of Operations Management, 24(6), 868-892. doi: 10.1016/j.jom.2005.11.006

Khandwalla, P. N. (1977). The design of organizations (Vol. 260). New York: Harcourt Brace Jovanovich.

Lai, K. H. (2003). Market orientation in quality-oriented organizations and its impact on their performance. International Journal of Production Economics, 84(1), 17-34. doi: 10.1016/S0925-5273(02)00382-1 
Lemak, D. J., Reed, R., \& Satish, P. K. (1997). Commitment to total quality management: is there a relationship with firm performance?. Journal of Quality Management, 2(1), 67-86. doi: 10.1016/S1084-8568(97)90022-5

Love, P. E., \& Edwards, D. J. (2005). Taking the pulse of UK construction project managers' health: Influence of job demands, job control and social support on psychological wellbeing. Engineering, Construction and Architectural Management, 12(1), 88-101. doi: 10.1108/09699980510576916

Nair, A. (2006). Meta-analysis of the relationship between quality management practices and firm performance - implications for quality management theory development. Journal of Operations Management, 24(6), 948-975. doi: 10.1016/j.jom.2005.11.005

Sadikoglu, E., \& Zehir, C. (2010). Investigating the effects of innovation and employee performance on the relationship between total quality management practices and firm performance: An empirical study of Turkish firms. International Journal of Production Economics, 127(1), 13-26. doi: 10.1016/j.ijpe.2010.02.013

Samson, D. \& Terziovski, M. (1999). The relationship between total quality management practices and operational performance. Journals of Operations Management, 17(4), 393-409. doi: 10.1016/S02726963(98)00046-1

Sharma, D. S. (2005). The association between ISO 9000 certification and financial performance. The international journal of accounting, 40(2), 151-172. doi: 10.1016/j.intacc.2005.01.011

Singh, P. (2008). Empirical assessment of ISO 9000 related management practices and performance relationships. International Journal of Production Economics, 113(1), 40-59. doi: 10.1016/j.ijpe.2007.02.047

Skerlavaj, M., Štemberger, M. I., \& Dimovski, V. (2007). Organizational learning culture - the missing link between business process change and organizational performance. International journal of production economics, 106(2), 346-367. doi: 10.1016/j.ijpe.2006.07.009
Spasojević Brkić, V., Klarin, M., Brkić, A., Lučanin, V. \& Milanović, D. D. (2011). Simultaneous consideration of contingency factors and quality management: An empirical study of Serbian companies. African Journal of Business Management, 5(3), 866-883. doi: 10.5897/AJBM10.559

Spasojević Brkić, V., Djurdjević, T., Dondur, N., Klarin, M. M., \& Tomić, B. (2013). An Empirical Examination of the Impact of Quality Tools Application on Business Performance: Evidence from Serbia. Total Quality Management \& Business Excellence, 24(5-6), 607-618. doi: 10.1080/14783363.2012.677306

Spasojević Brkić, V. (2009). Contingency Theory and Quality Management (in Serbian), monograph. Belgrade, Serbia: Faculty of Mechanical Engineering.

Tari, J., \& Sabater, V. (2004). Quality tools and techniques: Are they necessary for quality management?. International Journal of Production Economics, 92(3), 267-280. doi: 10.1016/j.ijpe.2003.10.018

Terziovski, M., \& Samson, D. (1999). The link between total quality management practice and organisational performance. International Journal of Quality \& Reliability Management, 16(3), 226-237. doi: 10.1108/02656719910223728

Tomić, B., Spasojević-Brkić, V. \& Klarin, M. (2012). Quality management system for the aerospace industry. Journal of Engineering Management and Competitiveness, 2(1), 11-15.

Vigoda-Gadot, E. (2007). Leadership style, organizational politics, and employees' performance: An empirical examination of two competing models. Personnel Review, 36(5), 661-683. doi: 10.1108/00483480710773981

Vroom, V.H. (1964). Work and Motivation. New York, NY: Wiley.

Živković, Ž., Mihajlović, I. \& Prvulović, S. (2009). Developing motivation model as a strategy for HRM in small enterprises under transitional economy. Serbian Journal of Management, 4(1), 1-27. 


\title{
OPERATIVNE PERFORMANSE I PERFORMANSE ZAPOSLENIH U SRPSKIM INDUSTRIJSKIM PREDUZEĆIMA SERTIFIKOVANIM PREMA ISO 9001
}

\begin{abstract}
Poslovne performanse se mere putem ključnih pokazatelja, koji opisuju stanje u preduzeću i devijacije od postavljenih ciljeva. U preduzečima ekonomija u tranziciji neophodno je obratiti posebnu pažnju praćenju mera poslovnih performansi. Najčešće razmatrani tipovi poslovnih performansi u literaturi su performance kvaliteta, operativne performanse, tržišne performanse, inovacione performance, performance projekata i zadovoljstva kupaca. $U$ ovom radu razmatrane su performanse zaposlenih i operativne performance na uzorku 113 srpskih industrijskih preduzeća. Nakon prikupljanja podataka putem upitnika, primenjene su deskriptivna statistika, faktorska i analiza pouzdanosti u cilju provere statistički značajnih dimenzija konstrukata performansi prema prethodnim istraživanjima. Pretpostavljene dimenzije su potvrdjene kao statistički značajne u opisivanju konstrukata, tako da su dobijeni rezultati su u skladu sa prethodnim istraživanjima sprovedenim u drugačijim kontekstima. Kao predlog daljih istraživanja daje se longitudinalna studija, kao i uključivanje drugih industrijskih sektora u analizu. Takodje je korisno istražiti i vezu izmedju operativnih i performansi zaposlenih.
\end{abstract}

Ključne reči: Operativne performanse, Performanse zaposlenih, Preduzeća, Srbija. 